\title{
La protection des droits fondamentaux des utilisateurs de FinTech: l'exemple de l'application du Règlement Général sur la Protection des Données
}

Loren Jolly

\section{Résumé:}

L'objectif de cet article est de mettre en évidence les différentes incertitudes que l'on rencontre lorsque l'on tente d'assurer l'application de leurs droits fondamentaux aux utilisateurs de FinTech. La protection des données et plus particulièrement les dispositions du Règlement Général sur la Protection des Données sont utilisées comme exemples dans cet article, afin d'illustrer les difficultés rencontrées. Ici, trois principales interrogations sont abordées: celles concernant les destinataires des dispositions du Règlement Général sur la Protection des Données, celles concernant les différences de traitement prévues par le Règlement Général sur la Protection des Données pour les données personnelles, pseudonymisées et les informations anonymes et enfin celles concernant la qualification des données disponibles sur des blockchains publiques et privées. Finalement cet article met en évidence les conséquences que ces incertitudes peuvent avoir sur la protection des droits fondamentaux des utilisateurs de FinTech ainsi que la nécessité d'assurer la sécurité juridique grâce à des instructions supplémentaires provenant du législateur européen ou grâce à la jurisprudence à venir.

\begin{abstract}
:
The aim of this article is to highlight the different issues that one faces when trying to ensure fundamental rights of FinTech users. Data protection and more especially the provisions of the General Data Protection Regulation are used as an example of the difficulties. Here, three principal issues are addressed: issues regarding the addressees of the General Data Protection Regulation's provisions, issues regarding the difference made in the General Data Protection Regulation between personal, pseudonymised and anonymised data and finally issues regarding the qualification and treatment of data available on permissionless and permissioned blockchains. Finally this article highlights the consequences that these uncertainties may have on the protection of FinTech's user's fundamental rights and the necessity to ensure legal certainty through additional guidance from the European legislator or upcoming case-law.
\end{abstract}

